\title{
A Study on the Motivation of APEC Volunteer and Its Relationship with Job Satisfaction
}

\author{
Shiqing Huang \\ Carey Business School, Johns Hopkins University, Baltimore, MD, USA \\ Email: fionashiqinghuang@jhu.edu
}

How to cite this paper: Huang, S.Q. (2017) A Study on the Motivation of APEC Volunteer and Its Relationship with Job Satisfaction. Journal of Service Science and Management, 10, 587-610.

https://doi.org/10.4236/jssm.2017.106044

Received: November 30, 2017

Accepted: December 26, 2017

Published: December 29, 2017

Copyright $\odot 2017$ by author and Scientific Research Publishing Inc. This work is licensed under the Creative Commons Attribution International License (CC BY 4.0).

http://creativecommons.org/licenses/by/4.0/

(c) (i) Open Access

\begin{abstract}
In the modern world, volunteering in international conferences is becoming more and more popular. In 2014, APEC conference has gained huge public attention. This research focuses on motivation and job satisfaction of APEC volunteers, and aims to find motivation difference of different demographic groups, as well as the relationship between motivation and job satisfaction. The research uses quantitative questionnaire method, and has analyzed data using SPSS software by single-factor analysis and regression analysis. The research has found self-growth and social demand as the strongest motivation dimensions for APEC volunteers, demographic variation for overall motivation and motivation dimensions, positive relationship between motivation and job satisfaction, positive relationship between altruism dimension and job satisfaction. The research will be useful in future volunteering promotion, recruiting, selection, training and motivation of large national conference, competition, and exhibitions.
\end{abstract}

\section{Keywords}

APEC Volunteers, Motivation, Job Satisfaction

\section{Introduction}

In the modern era, volunteers are actively involved in different aspects of society. They never stop their steps and dedicated devotion to large international competition, activities, and exhibitions held by China, such as Olympic Games, World Expo, Garden Expo, etc. Nowadays, in the large international forum APEC held by China, volunteers have played an important role. According to the report of China News Agency [1], 2014 APEC Leaders' meeting was held in Beijing in November, and 2280 youth volunteers served in 7 sectors, 39 business ports, 139 level-1 positions and 87 level-2 positions. Among all the large interna- 
tional events held in Beijing, this voluntary service covers the widest area and has the greatest varieties of positions. APEC volunteers have drawn huge public attention again as large event volunteers.

However, there is little research on motivation of volunteers in Chinese literature, let alone research on APEC specifically. That is why this research is intended to explore the motivation of APEC volunteers, and study the relationship between motivation and their job satisfaction.

This research exams how motivated volunteers are and why they apply for the APEC volunteering position; Also, the research looks into demographic data (grade, age, gender, major, and political status) of volunteers and analyzes the motivation difference among different demographic groups; Then job satisfaction is measured, and the relationship between overall motivation/motivation dimensions and job satisfaction is analyzed.

Research on the motivation of APEC volunteers is both theoretically and practically important. Theoretically, it will solve the lack of research on APEC volunteers in China. Practically, it will provide reference for future promotion, recruiting, selection, training, motivation of volunteers for the national large events and competitions in the future. The research can also help find out the administration area to be focused on, in order to motivate more volunteers to apply, and to improve their motivation. Research on the relationship between volunteer motivation and their job satisfaction can guide administration on volunteers, stimulate their motivation, and enhance their job satisfaction.

\section{Literature Review}

\subsection{Volunteer Motivation}

Scholars started to pay attention to volunteer motivation from the 1970s [2]. In 1981, Frisch and Gerrard constructed two-factor model in the study on Red Cross volunteers, and found the altruistic motives (motives for the benefit of others) and selfish motives (motives for the benefit of oneself) [3]. Afterwards, Esmond also proposed three-factor model, linear model, and multi-factor model as volunteer motivation models [4].

Compared with systematic study on volunteer motivation in the other countries, China is still in the beginning stage in this area [2].

In the recent years, there has been some development in the Chinese research on the motivation of volunteers. The attention which Chinese scholars paid to volunteer motivations has increased recent years. They are trying to study volunteer motivation for large international competitions, conference, and exhibitions held in China, produced research such as Study on the Participation Motivation of Volunteers in Olympic Games [5], Motivation of College Volunteers in Xi'an Global Garden Expo [6].

In general, research on volunteer motivation in APEC is very limited. On the one hand, there are many researches on volunteer motivation in the large com- 
petitions and exhibitions held in China, but only a few researches are related to that in large international conferences, especially APEC conference. On the other hand, even for some studies related to APEC, volunteer motivation is not widely-discussed. Most of the studies on volunteers in 2013 Shanghai APEC are concentrated on emotional interview, showing the lack of standard academic study about volunteer motivation in APEC [7]. For this year's APEC (2014 in Beijing), the number of volunteer is large, voluntary services are covered widest, and there are the largest number of positions among all the large international conferences held in Beijing, but there are no currently published researches on volunteer for this 2014 APEC, due the late selection of volunteers till October 2014.

Based on the two reasons mentioned above, research on volunteer motivation in China is only at the beginning stage with limited development; There is not enough research on APEC volunteer in China. To solve the inadequacy of previous research on APEC volunteer in China, this research plans to focus on 2014 APEC volunteers to study their registration motivation.

According to the literature of Motivation and Incentive System of Xi'an Global Garden Expo University Student Volunteers [6], with the addition of reference to Voluntary Work of University Student Volunteers in Chinese Large Sports Events [8] and Incentive System of University Student Voluntary Service [9], this research categorizes voluntary motivation into "self-growth", "social demand", "self realization", "altruism", "dream realization", "environmental factor", "honor motivation", and "compensation exchange" eight dimensions in all.

In this research, "overall motivation" means the intensity of overall motivation of volunteers investigated, and is calculated with arithmetic mean of the above eight dimensions.

Specifically, those eight dimensions are defined as follows:

Self-growth refers to the hope of individuals to discover their own potential and understand themselves, through participating voluntary service, which is beneficial for climbing up the career ladder and improving themselves.

Social demand refers to the motivation to enlarge social circle and know more friends. Voluntary activities are with no doubt an excellent platform for college students to get touch with different groups of people and expand their social network.

Self-realization means the motivation to obtain the feeling of satisfaction and achievement through voluntary service, in order to realize themselves, and thus reflect self-value.

Altruism refers to the voluntary motivation to benefit others without selfish tendency. It is also related to motivation to help the development of society and help people in need to repay society, which is a selfless motivation with consideration of others.

Dream realization refers to the motivation, where university students want to realize a better, more impartial, and more democratic society through voluntary 
activities.

Environmental factors refer to the motivation affected by surrounding people, things, own experience and status, and other objective environmental, to participate in voluntary service.

Honor motivation refers to the motivations that volunteers obtain praise from society. For example, for current university students, recognition and honor from school and society, praise from boss, from people who receive their voluntary service, from classmates and friends, can all encourage the honor motivation of them.

Compensation exchange refers to motivation to pursuit extra points in school evaluation, job offers, graduate admission, material rewards and other compensation.

\subsection{Volunteer Job Satisfaction}

In the research of Galindo-Kuhn and Guzley in year 2001, volunteers' satisfaction index (VSI) was categorized according to 10 aspects of influence: Organizational support, Participation efficacy, Empowerment, Group integration, Values, Understanding, Enhancement, Career, Social, and Protective, among which the explanation of Values is: to express important values, such as altruism [10]. The motivation of volunteers (altruism and selfish motives) can be understood as specified values. As a result, this research assumes that different volunteer motivation can be related with different levels of voluntary job satisfaction.

Besides, some researches also include both volunteer motivation and volunteer job satisfaction into variables for correlation analysis. For example, Clary et al have found that volunteer motivation and the matchness between expected compensation and real compensation can be significant predictors of job satisfaction and burnout [11], but there are few studies directly looking into the relationship between volunteer motivation and job satisfaction. Based on the previous literature and due to insufficiency of past research, this research is going to focus on the relationship between volunteer motivation and job satisfaction, investigating current large number of and widely impacting APEC volunteers, to study the relationship between motivation of APEC volunteers and their job satisfaction.

But more studies on volunteer job satisfaction do not analyze its correlation with volunteer motivation. More volunteer job satisfaction literatures are investigating relative factors such as trust, organizational commitment, and psychological contract (Starnes, 2007). Although most of them are related to organizational behavior and employee psychology, none of them is exactly focusing on the relationship of job satisfaction with motivation.

\section{Research Objectives and Methodology}

The main content of this research are shown in Table 1 (also see Figure 1). Specifically, the research objectives are: 1) to explore recognition degree of different 
Table 1. Minnesota satisfaction questionnaire (Part).

\begin{tabular}{|c|c|c|c|c|c|c|}
\hline & $\begin{array}{l}\text { How do you feel about } \\
\text { your current job }\end{array}$ & $\begin{array}{l}\text { Very dissatisfied } \\
\qquad=1\end{array}$ & $\begin{array}{l}\text { Dissatisfied } \\
\quad=2\end{array}$ & $\begin{array}{l}\text { Uncertain } \\
\quad=3\end{array}$ & $\begin{array}{l}\text { Satisfied } \\
\quad=4\end{array}$ & $\begin{array}{l}\text { Very Satisfied } \\
\quad=5\end{array}$ \\
\hline 1 & $\begin{array}{l}\text { Can always keep busy } \\
\text { status }\end{array}$ & & & & & \\
\hline 2 & $\begin{array}{c}\text { Opportunity of } \\
\text { independent work }\end{array}$ & & & & & \\
\hline 3 & $\begin{array}{l}\text { Opportunity to do } \\
\text { different things at time }\end{array}$ & & & & & \\
\hline 4 & $\begin{array}{l}\text { Opportunity to become } \\
\text { an import role in team }\end{array}$ & & & & & \\
\hline
\end{tabular}

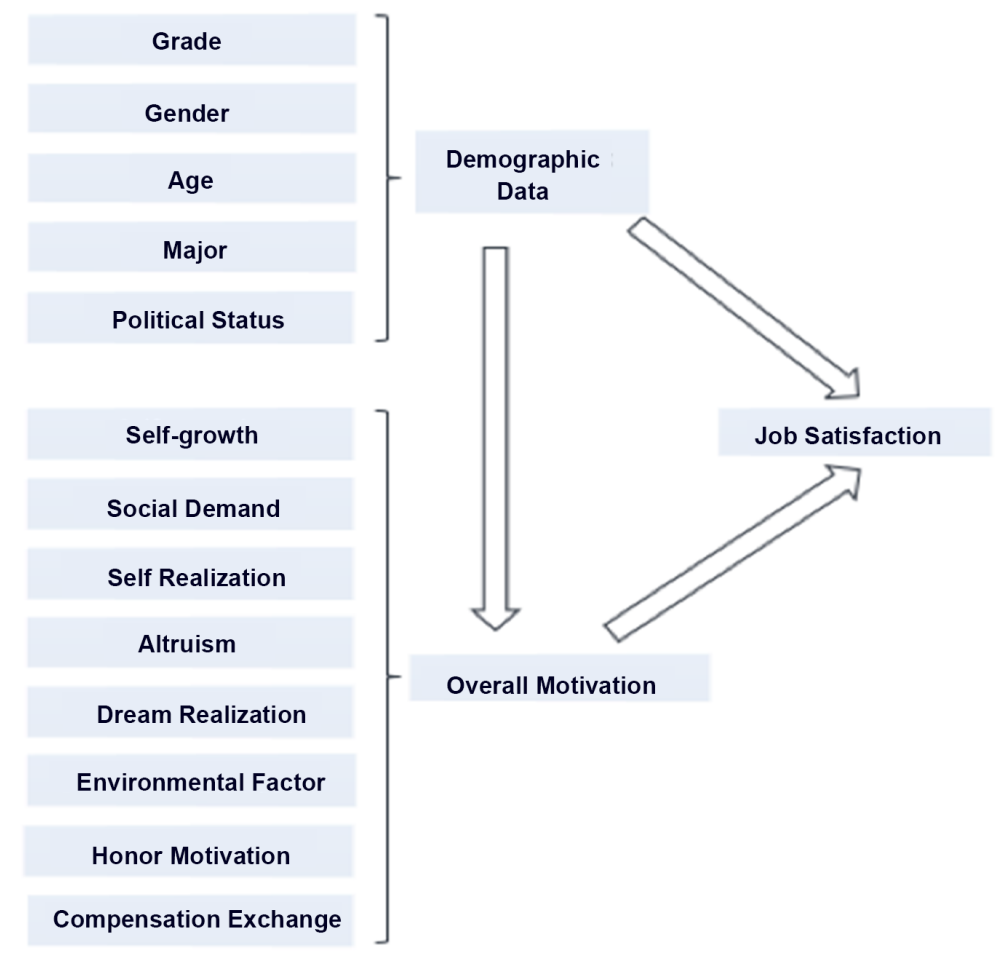

Figure 1. Research contents (Source: objective and model of this research).

dimensions of motivation among all samples; 2) to explore the different overall motivation of different demographic groups; 3) to explore the different motivation dimension inclination of different demographic groups; 4) to explore the relationship between overall motivation and job satisfaction (demographic data as controlled variable); 5) to explore the relationship between different motivation dimensions and job satisfaction (demographic data as controlled variable).

In order to complete the objectives, this research will use questionnaire as the main method.

The measures of motivation in this research is based on the scales in Motivation and Incentive System of Xi'an Global Garden Expo University student volunteers [6], also taking into account the research Voluntary Work of University Student Volunteers in Chinese Large Sports Events [8] and Incentive System of 
University Student Voluntary Service [9], and eventually formulated a questionnaire with 8 dimensions ("self-growth", "social demand", "self realization", "altruism", "dream realization", "environmental factor", "honor motivation", and "compensation exchange"), 26 questions.

Besides, to measure the job satisfaction degree, this research adopted Minnesota satisfaction degree questionnaire (short) [12], 20 questions in total (partially presented in Table 1).

After the data collection, this research will use SPSS questionnaire to conduct data analysis. Arithmetic means calculation will be used to look at different dimensions of motivation among all samples. Regression analysis will be used to test different overall motivations of different demographic samples, as well as relationship between overall motivation and job satisfaction, and relationship between each motivation dimension and job satisfaction. Single-factor analysis will be used to measure difference between various dimensions of motivation among different demographic samples.

\section{Empirical Results}

This year's APEC administration department has recruited 2280 volunteers from 23 universities, including 654 male students (28.68\%) and 1626 female students (71.32\%). There are 1660 undergraduate students (72.81\%), 600 graduate students $(26.32 \%)$, and $20 \mathrm{PhD}$ students $(0.69 \%)$. There are 1530 Communist Youth League members (accounting for $67.11 \%$ of total members), and 750 Member of Chinese Communist (accounting for 32.89\% of total members) [13].

In total, 200 questionnaires have been distributed, and 186 of them were returned, with return rate of $93 \%$. Among them, 183 questionnaires were effective, with effective rate of $98.39 \%$. Effective questionnaires come from Beijing International Studies University, Beijing University of Technology, Beihang University, Beijing Institute of Technology, Beijing Union University, Beijing Normal University, Beijing Language and Culture University, China Foreign Affairs University, China University of Geosciences, China Women's University, and Central University of Finance and Economics, all 11 in total. The sample number takes up $8.78 \%$ of the total volunteer population, with $8.03 \%$ of population as effective sample, which is qualified sample quantity.

In the 183 effective questionnaires, there are 56 males (30.60\% of sample), 127 females $(69.40 \%$ of sample). There are 126 undergraduate students $(68.85 \%$ of sample), 56 master students (30.60\% of sample), and $1 \mathrm{PhD}$ student $(0.55 \%$ of sample). Major distribution includes 112 liberal and art students (including econ and management, $61.20 \%$ of sample) and 71 science or engineering students (38.80\% of sample). There are 126 Youth League members (including enthusiast for Communist Party but have not joined the Party yet) (68.85\% of sample), and 57 Party members (including prepared Party members) (31.15\% of sample). The sample demographic distribution (see Figure 2) is generally consistent with the population demographic distribution. 


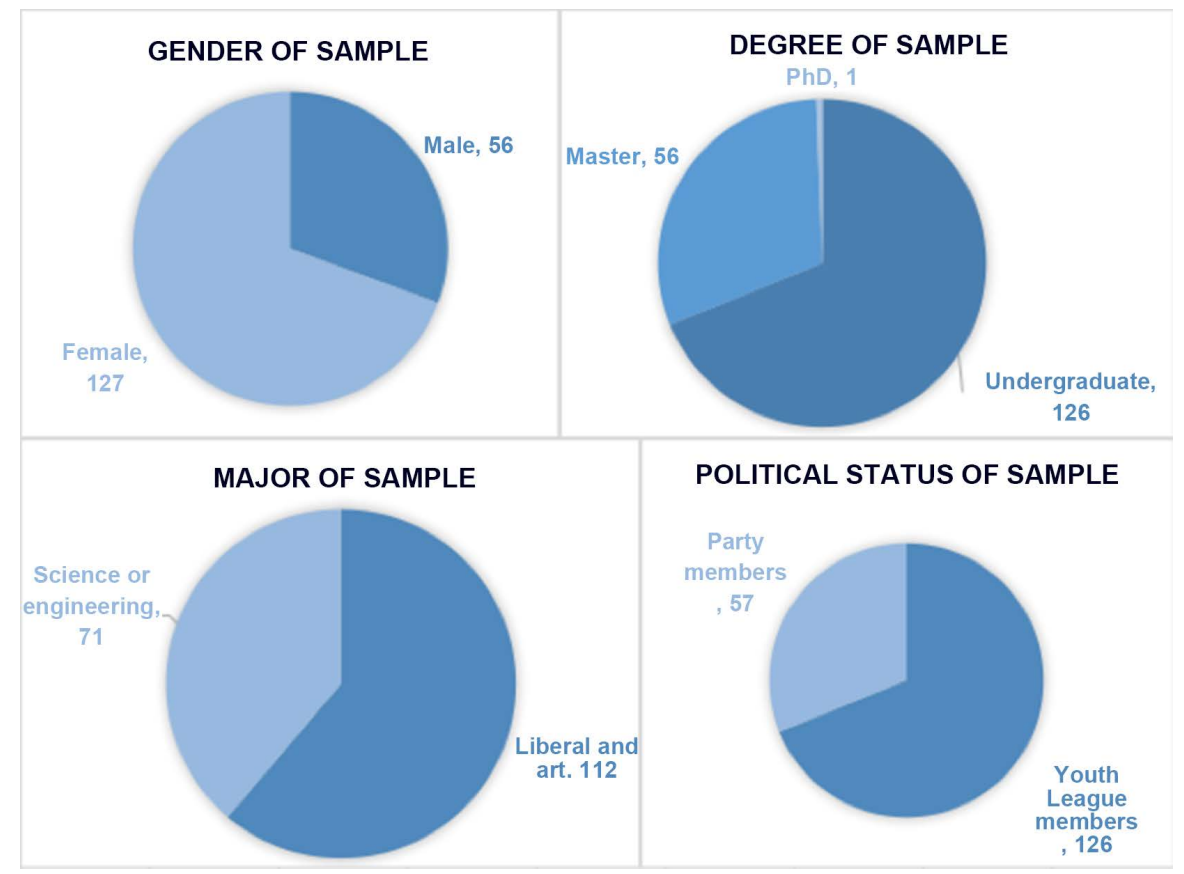

Figure 2. Sample demographic distribution (Source: questionnaire collection of this research).

\subsection{Different Dimensions of Motivation among All Samples}

This research calculated points for each motivation dimension by using arithmetic means of results from questions which measures that specific dimension, and then come into each got the total value of each dimension, shown as below.

As shown in Figure 3, among all the effective 183 samples, the strongest motivations of volunteers come from self-growth (mean 4.52 out of 5) and social demand (mean 4.45 out of 5). Comparatively strong motivations include dream realization (mean 4.39 out of 5), altruism (mean 4.22 out of 5), and self-realization (mean 4.14 out of 5 ). The weakest motivations are compensation exchange (mean 2.61 out of 5) and environmental factor (mean 3.11 out of 5).

\subsection{Different Overall Motivations of Different Demographic Samples}

This research used demographic data, grade, gender, age, major, political status, respectively as independent variables one by one, and used overall motivation as dependent variable to conduct regression analysis. The result of regression analysis is shown as below.

According to Table 2, the relationship between grade and overall motivation is significant on 0.1 level (Sig. $=0.005$ ), with correlation coefficient of -0.184 , which means that overall motivation may decrease for sample student volunteers with their grade increasing.

The relationship between age and overall motivation is significant on 0.1 level (Sig. $=0.010)$, with correlation coefficient of 0.128 , which means older students may have higher level of overall motivation. 
Compensation Exchange

Honor Motivation

Environmental Factor

Dream Realization

Altruism

Self Realization

Social Demand

Self-growth
2.61

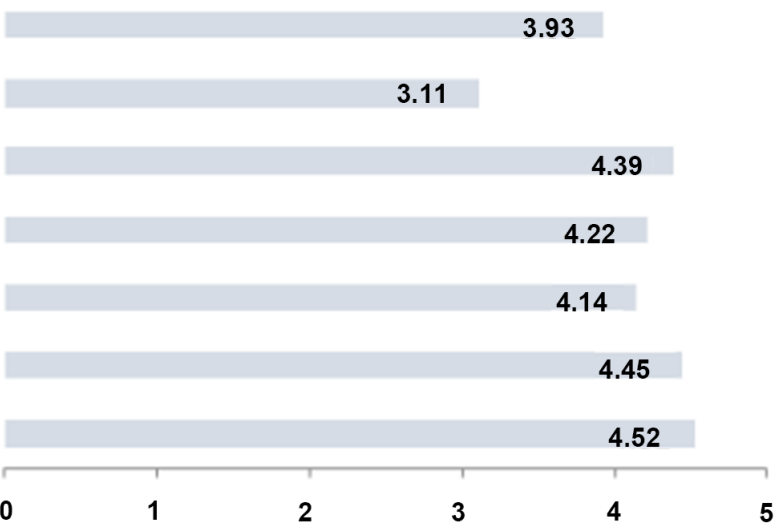

Figure 3. Different dimensions of motivation among all samples (Source: questionnaire collection of this research).

Table 2. Different overall motivations of different demographic samples.

\begin{tabular}{|c|c|c|c|c|c|}
\hline \multicolumn{6}{|c|}{ Coefficient $^{\mathrm{a}}$} \\
\hline \multirow{2}{*}{ Model } & \multicolumn{2}{|c|}{ Non-standard coefficient } & \multirow{2}{*}{$\begin{array}{c}\text { Standard coefficient } \\
\text { Trial }\end{array}$} & \multirow{2}{*}{$\mathrm{t}$} & \multirow{2}{*}{ Sig. } \\
\hline & B & Standard error & & & \\
\hline (Constant) & 1.608 & 0.928 & & 1.733 & 0.085 \\
\hline Grade & -0.184 & 0.065 & -0.432 & -2.814 & 00.005 \\
\hline Gender & -0.129 & 0.092 & -0.109 & -1.393 & 0.165 \\
\hline Age & 0.128 & 0.049 & 0.382 & 2.616 & 0.010 \\
\hline Major & 0.090 & 0.087 & 0.081 & 1.030 & 0.305 \\
\hline Political status & 0.175 & 0.096 & 0.150 & 1.824 & 0.070 \\
\hline
\end{tabular}

a. Dependent variable: Overall motivation.

The relationship between political status and overall motivation is significant on 0.1 level (Sig. $=0.070$ ), with correlation coefficient of 0.175 , which is to say, with the aspect of political status, Communist Party members have stronger overall motivation than Communist Youth League members.

\subsection{Difference between Various Dimensions of Motivation among Different Demographic Samples}

This research numbered demographic data, grade, gender, age, major, and political status, as $102,103,104,105,106$, and used 8 dimensions of motivation (self-growth, social demand, self-realization, altruism, dream realization, environmental factor, honor motivation, compensation exchange) as dependent variable. Five demographic data are used as factor to conduct single factor analysis.

\subsubsection{Grade}

Grades ranging from first year, second year, junior, senior, to first year graduate, 
second year graduate, third year graduate, first year $\mathrm{PhD}$, second year $\mathrm{PhD}$ were numbered as $1,2,3,4,5,6,7,8$, 9. Single factor analysis used eight dimensions of motivation (self-growth, social demand, self-realization, altruism, dream realization, environmental factor, honor motivation, compensation exchange) as dependent variable, and grades as factor. The results of analysis are shown in Table A1.

According to Table A1 and mean graphs, only one dimension, compensation exchange, is both significant (Sig. $=0.044$ ) and having a clear trend, which is to say, different grades have significant difference in the "Compensation Exchange" motivation dimension. The mean of "Compensation Exchange" has the trend with the change of grades shown in the figure below.

According to Figure 4, the general trend is: with the increase of grade, the mean of compensation exchange will decrease, with small volatility, which is to say, volunteers in higher grades have less motivation to pursuit extra points in school evaluation, job opportunity, graduate admission, material rewards as compensation.

\subsubsection{Gender}

This research numbered male and female as 1 and 2. It treated eight motivation dimensions (self-growth, social demand, self-realization, altruism, dream realization, environmental factor, honor motivation, compensation exchange) as dependent variables, and gender as factor, to conduct single factor analysis. Results are in Table A2.

Based on the Table A2 and mean graphs, only three factors, self-realization $($ Sig. $=0.022)$, environmental factor $($ Sig. $=0.039)$, honor motivation (Sig. $=$ 0.004 ), are significant and have clear trends, which is to say, different gender samples have significant difference in the motivation dimensions of self-realization, environmental factor, and honor motivation. The trends of self-realization, environmental factor, and honor motivation are presented in the following graphs (Figure 5, Figure 6).

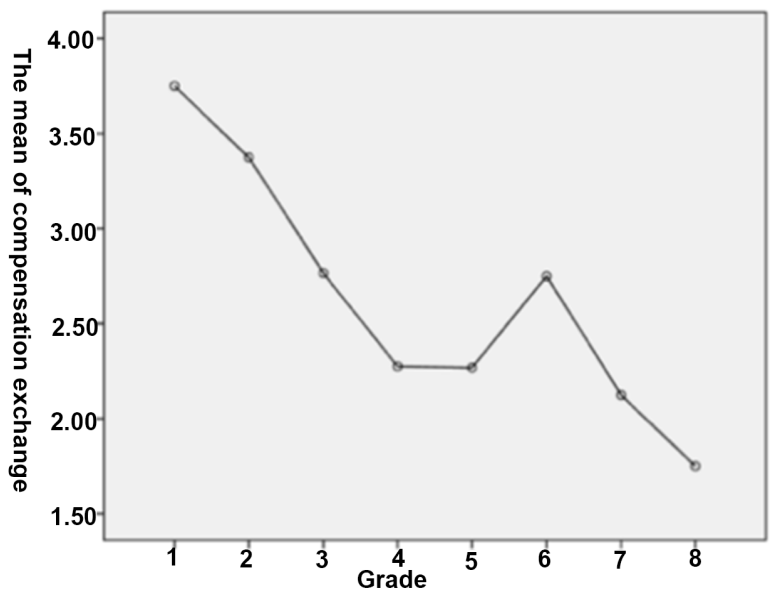

Figure 4. Trend of compensation exchange mean with regard to grades (Source: questionnaire collection of this research). 


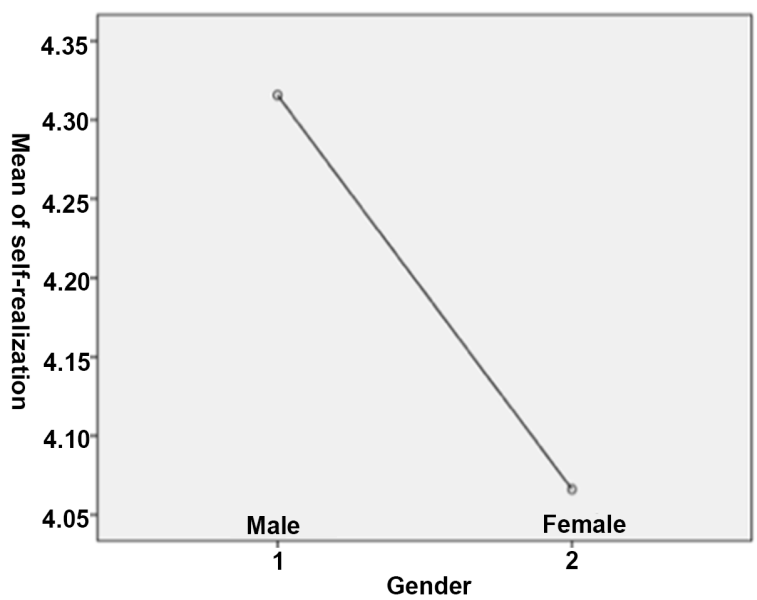

Figure 5. Trend of self-realization mean with regard to gender (Source: questionnaire collection of this research).

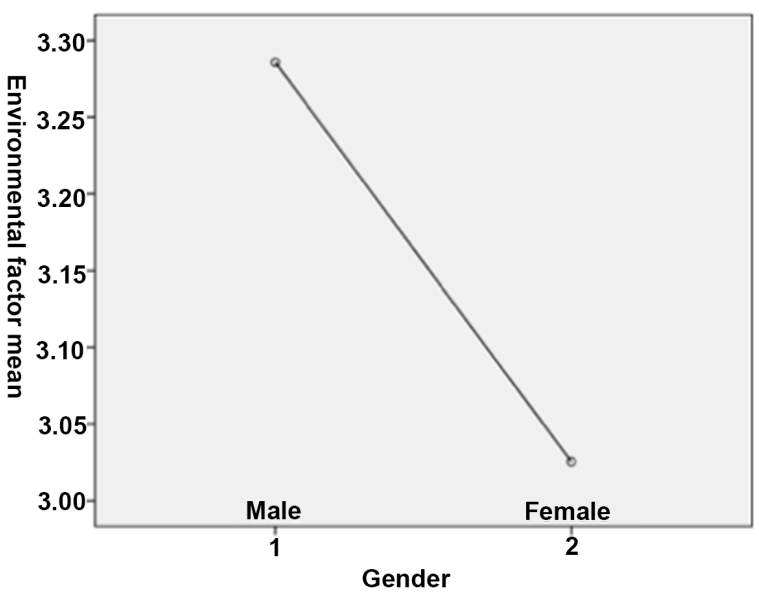

Figure 6. Trend of environmental factor change with regard to gender (Source: questionnaire collection of this research).

From Figure 5, male students have the general trend with more self realization motivation than female students, which is to say, compared with female students, male students have more motivation to obtain the feeling of satisfaction and achievement, in order to realize themselves, and reflect their values.

From Figure 6, the general trend is that male students have stronger motivation in environmental factor than female students, which is to say, when male students register as volunteers, they are more likely influenced by the surrounding environments compared with female students.

Figure 7 shows that male students have a general trend with higher honor motivation than female students. Consequently, compared with female students, male students want to get more praise and recognition from society.

\subsubsection{Age}

This research used eight motivation dimensions (self-growth, social demand, self-realization, altruism, dream realization, environmental factor, honor 


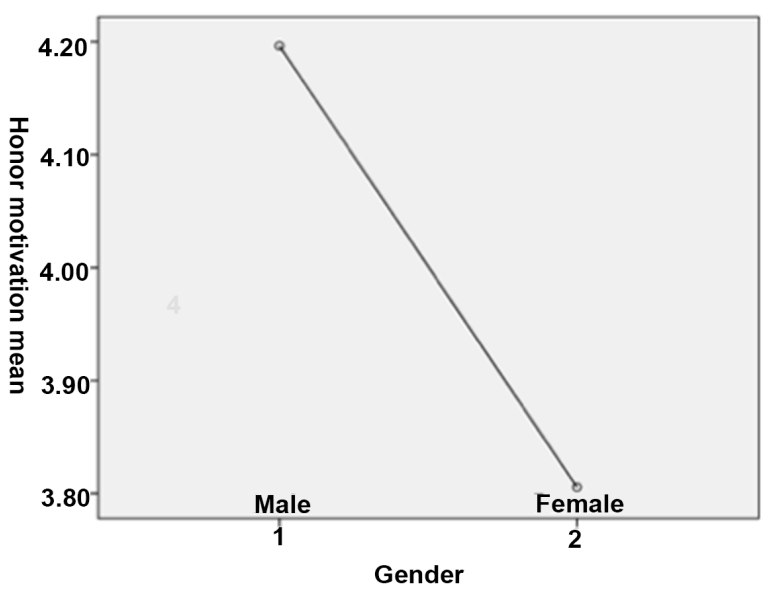

Figure 7. Trend of honor motivation mean with regard to gender (Source: questionnaire collection of this research).

motivation, compensation exchange) as dependent factor, and grade as factor to conduct single factor analysis, with the results in Table A3.

According Table A3, only one dimension, dream realization, is significant $($ Sig. $=0.098)$, but from the mean graph, there is no significant trend of dream realization dimension with age change.

\subsubsection{Major}

This research numbered liberal art and history major (including economics and management) as 1 , and science and engineering major as 2 . It also used eight motivation dimensions (self-growth, social demand, self-realization, altruism, dream realization, environmental factor, honor motivation, compensation exchange) as dependent factor, and major as factor to conduct single factor analysis, with the results in Table A4.

According to Table A4 and analyzed mean graph, only one dimension, honor motivation, is significant (Sig. $=0.027$ ), and with clear trend, which is to say, different major samples have significant difference in honor motivation. The trend of honor motivation mean with grade change is presented in the following graph.

According to Figure 8, the general trend is that, students majoring in science or engineering have comparatively higher motivation in honor than students majoring in liberal art and history, which is to say, compared with liberal art and history students, science and engineering students have stronger motivation to get praise from society.

\subsubsection{Political Status}

This research assigned number 1, 2, 3 respectively to student from neither Communist Youth League nor Communist Party, student from Communist Youth League, and student from Communist Party. Since one of criteria for this volunteer selection is $100 \%$ Youth League members or Communist Party members, there is no sample falling into political status 1 (student from neither Communist Youth League nor Communist Party). This research used eight 


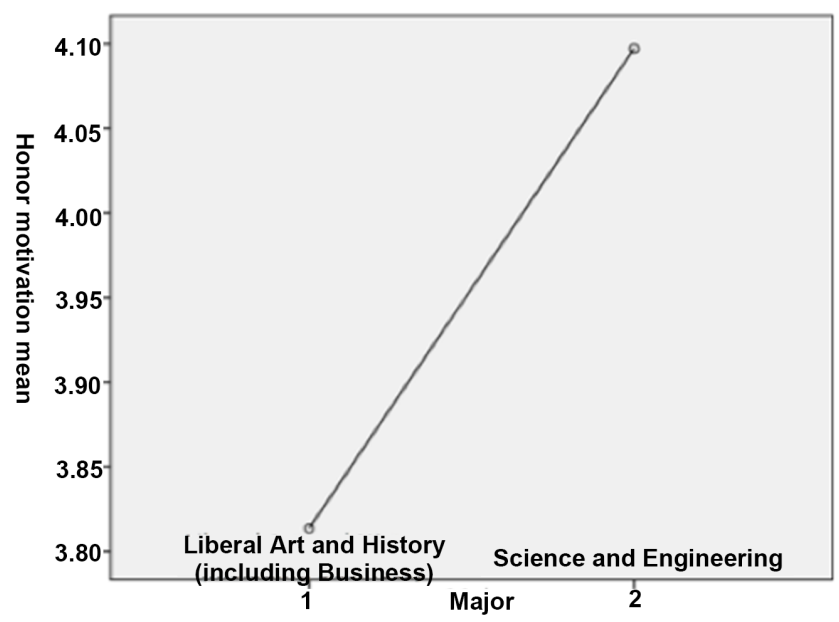

Figure 8. Trend of honor motivation mean with regard to major (Source: questionnaire collection of this research).

motivation dimensions (self-growth, social demand, self-realization, altruism, dream realization, environmental factor, honor motivation, compensation exchange) as dependent factor, and political status as factor to conduct single factor analysis, with the results in Table A5.

According Table A5 and analyzed mean graph, motivation dimension of dream realization (Sig. $=0.064<0.1)$ and honor motivation $($ Sig. $=0.001<0.1$ ) are significant with clear trend, which is to say, different political status samples have significant difference in dream realization and honor motivation. The trends of dream realization and honor motivation mean with political status change are presented in the following graph.

According to Figure 9, the general trend is that, Party members have comparatively higher motivation in honor than Youth League members. So, compared with Youth League members, Party members have stronger motivation to make the society more impartial, democratic and better through voluntary activities.

According to Figure 10, the general trend is that, Party members have comparatively higher motivation in honor than Youth League members, which is to say, compared with Youth League members, Party members have stronger motivation to get praise from society.

\subsection{Relationship between Overall Motivation and Job Satisfaction}

This research set demographic data (grade, gender, age, major, and political status, numbered as $102,103,104,105,106)$ as controlled variables, overall motivation as independent variable, and job satisfaction as dependent variable, to conduct regression analysis. The result of regression analysis is in Table A6.

All demographic variables are not significantly related to "job satisfaction", because significance levels are all higher than 0.1 . That is to say, difference in grade, gender, age, major, and political status are not affecting job satisfaction of APEC volunteers. 


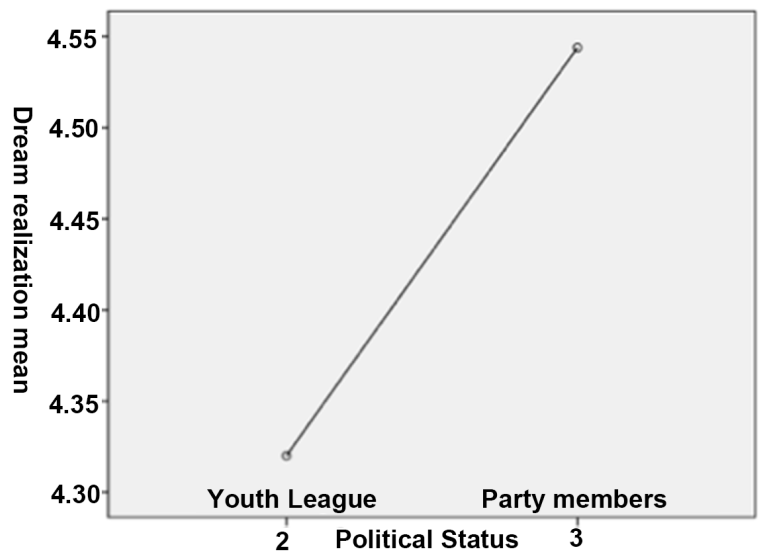

Figure 9. Trend of dream realization mean with regard to political status. (Source: questionnaire collection of this research).

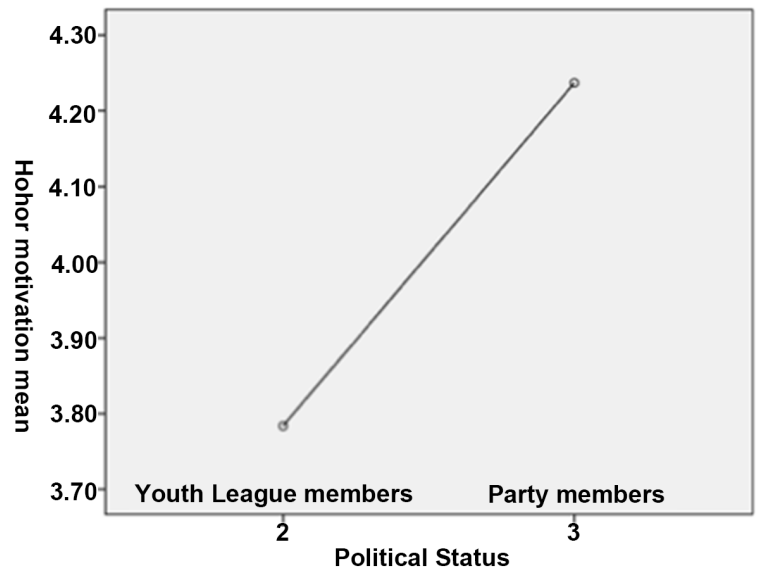

Figure 10. Trend of honor motivation mean with regard to political status (Source: questionnaire collection of this research).

According to Table A6, with demographic data fixed, the relationship between overall motivation and job satisfaction is very significant (Sig. $=0.000$ ), with a very strong positive correlation (correlation coefficient $=0.486$ ).

\subsection{Relationship between Each Motivation Dimension and Job Satisfaction}

This research numbered demographic data into 102, 103, 104, 105, 106 according to grade, gender, age, major, and political status. These five demographic data are set as controlled variables, 8 motivation dimensions (self-growth, social demand, self-realization, altruism, dream realization, environmental factor, honor motivation, compensation exchange) as independent variables, and job satisfaction as dependent variable, in order to conduct regression analysis. The result of regression analysis is in Table A7. 
According to Table A7, among all the eight motivation dimensions, only altruism has significant relationship with job satisfaction (Sig. $=0.066<0.1$ ), with the correlation coefficient of 0.156 , which is to say, volunteers with higher altruism motivation are predicted to have higher job satisfaction. On the contrary, all other 7 dimensions (self-growth, social demand, self-realization, dream realization, environmental factor, honor motivation, compensation exchange) of motivation do not have significant relationship with "job satisfaction", because their significance level of regression as independent variables are all greater than 0.1.

\section{Implications and Limitations}

\subsection{Recognition Degree among Different Motivation Dimension in All Samples}

From Figure 3, in all effective 183 samples, the strongest motivations come from self-growth (mean 4.52 out of 5) and social demand (mean 4.45 out of 5), and the weakest motivation dimensions are compensation exchange (mean 2.61 out of 5) and environmental factor (mean 3.11 out of 5). This indicates that most of volunteers in this year's APEC applied for APEC voluntary service in order to discover own potential, know themselves, improve themselves, enlarge social circle, and know more friends through the participation of voluntary service. At the same time, the motivations out of the pursuit of extra points in school evaluation, job offer, graduate admission, material compensation and other rewards, and out of the impact of surrounding environment, are comparatively weak.

As a one of large conference, events, and exhibition, APEC is a good model to research on volunteers' motivation; And the research is meaningful for the recruitment and training of volunteers in other large events.

In order to improve the motivation of volunteers and realize this motivation in daily work to activate higher motivation of volunteers, APEC administrative department should pay more attention to the recruitment and training of the volunteers for the future large events. For example, during the promotion of volunteers recruiting, it is necessary to emphasize that voluntary work can enhance personal capability, expand social circle, in order to attract more brilliant university students to participate. Comparatively, it is less important to promote the effect on the school evaluation, job opportunity, graduate admission, material compensation, and it is not proper to promote voluntary service for killing time or for the reason of following others. Another example is to train volunteers with the following idea: "Completing voluntary job well can improve capability, help achieve expected objective, and help learn the knowledge you wanted", "Through actively involved in work, one can enlarge personal connection and know more friends who cherish the same ideals and follow the same path". Training should also emphasize the excellence of selected volunteers and growth opportunity in capability, knowledge, and connection. During the training, it is useless to mention any motivation related to extra points, resume, material factors, and environment. 


\subsection{Difference in Overall Motivation among Demographic Data Sample}

According to Table 2, in the aspect of political status, Party members have stronger overall motivation than Youth League members. With the consideration of this aspect, it is reasonable for large events to consider political status in their volunteer recruiting, since Party members on average may have stronger overall motivation than Youth League members.

\subsection{Difference of Each Motivation Dimension among Demographic Data Sample}

Firstly, volunteers with higher grade have weaker motivation to pursuit better evaluation, extra points, job opportunities, graduate admissions, material rewards and other compensation. This is possibly because students in higher grades have clearer understanding with themselves, and they will not register for APEC volunteers blindly due to non-important short-term benefit or material temptation.

Secondly, Party members pay more attention to honor motivation and dream realization than Youth League members. Compared with Youth League members, Party members care more about whether to get the praise from society, and also more about making the society more impartial, democratic, and better through voluntary activities. With the combination in Section 5.2, it could be considered in the future to include "Party members preferred" in the selection criterion. On the other hand, motivation to Party members should focus on the social responsibility and honor awareness.

\subsection{Relationship between Overall Motivation and Job Satisfaction}

According to Table A6, after the control of demographic statistics, overall motivation has a very significant relationship with job satisfaction (Sig. $=0.000$ ), and the positive correlation is very strong, with correlation coefficient of 0.486 .

Therefore, volunteer motivation is very essential, and the improvement of volunteer motivation can largely enhance their job satisfaction; Job satisfaction is naturally and closely related to work efficiency and work motivation. Volunteer motivation is not only related to a single volunteer, it is related to whether many volunteers are content with voluntary work, and whether they are likely to complete work well. As a result, the future volunteer events should increase emphasis on volunteer motivation. What volunteers want to obtain should be promoted to volunteers, and the organizations should also try best to satisfy their need in capability improvement, social circle enlarge, contribution to society, and pursuit for rewards, but should note that they have different desire degree in each aspect.

For now, there is not much research on the motivation and satisfaction of volunteers from large conference, competition, exhibitions and other large events in China. In the future, scholars should pay more attention to volunteer motivation and satisfaction. 


\subsection{Relationship between Each Motivation Dimension and Job Satisfaction}

Altruism has significant relationship with job satisfaction (Sig. $=0.066<0.1$ ), with correlation coefficient of 0.156 , which is to say, higher motivation of altruism leads to better job satisfaction.

During the process of promoting volunteer registration and benefits of voluntary participation, the organization should not only consider what volunteers care most (i.e. analysis in 5.1 "Recognition degree among different motivation dimension in all samples"), but also should consider which aspects when volunteers put their focus and desire on. With the consideration of the two perspectives, volunteer job satisfaction can be largely increased. In this way, organization can better improve their work motivation and efficiency.

In the promotion, apart from the self-growth and social demand mentioned in 5.1, altruism should also be emphasized. When volunteers think they are doing voluntary service for helping others, taking their responsibility, and repaying for society, they can be more satisfied with work and can demonstrate higher motivation and efficiency.

Apart from the innovative result findings, it should be admitted that this research does have limitations. The first limitation is questionnaire quantity. Due to the limitation of funding and materials, the number of questionnaire is still not enough. Ideal questionnaire quantity should achieve 200 effective questionnaires, whereas this research only has effective questionnaires of 183 .

The second limitation is regarding how well the questionnaires are completed. It is not known whether each participant has answered all questions with high seriousness. For example, among 186 returned questionnaires, there were 3 invalid ones. 2 of them were incomplete, and 1 was not taken seriously, every question having the same answer choice " 5 ". This may be due to too many questions on questionnaire, tiring work, or no material rewards for taking questionnaires. In the future similar research, it is recommended to provide some material motivation for each survey participants.

\section{Conclusions}

The objective of this research is to explore the relationship between APEC volunteers' motivation and job satisfaction.

This research adopted methodology of document analysis and questionnaire survey, and categorized volunteer motivation into 8 dimensions: self-growth, social demand, self realization, altruism, dream realization, environmental factor, honor motivation, and compensation exchange. This research selected 200 students from 11 universities to take questionnaire survey, including Beijing International Studies University, Beijing University of Technology, Beihang University, Beijing Institute of Technology, Beijing Union University, Beijing Normal University, Beijing Language and Culture University, China Foreign Affairs University, China University of Geosciences, China Women's University, and 
Central University of Finance and Economics, with 183 effective surveys returned.

This research adopted SPSS for data analysis, and has come to the following conclusions: First, the strongest motivation comes from self-growth and social demand, while the weakest motivation dimensions are compensation exchange and environmental factor. Second, Party members have stronger overall motivation than Youth League members; Students with older age and higher grades are more likely to have higher overall motivation than students with younger age and lower grades. Third, different grades, genders, major, political status lead to different motivation dimensions: volunteers with higher grades have less motivation towards extra points for school evaluation, job offer, graduate admission, material rewards, and other compensation. Male volunteers have stronger motivation in self-growth, environmental factors, and rewards motivation. Also, Party members place more value on rewards motivation and dream realization than Youth League members. Fourth, overall motivation has a very strong $(\mathrm{B}=$ 0.486 ) and significant (Sig. $=0.000)$ positive relationship with job satisfaction. Fifth, the stronger altruism motivation is, the better the job satisfaction is.

At last, this research conducts analysis and discussion on each result conclusion. Although the data quantity and completion rate is not the most ideal, this research does propose recommendations for large events in the future on volunteer promotion, recruiting, selection, training, and motivation.

\section{References}

[1] China News Agency (2014) 2280 Volunteers Serve APEC Conferences, with Most Variety of Volunteer Job Types in Beijing Large Event Volunteer Service History. http://society.people.com.cn/n/2014/1025/c136657-25907261.html

[2] Yang, X. (2011) Research on Volunteer Motivation in Foreign Countries and Its Enlightenment. Contemporary Youth Studies, 1, 17-20.

[3] Frisch, M.B. and Gerrard, M. (1981) Natural Helping Systems: A Survey of Red Cross Volunteers. American Journal of Community Psychology, 9, 567-579. https://doi.org/10.1007/BF00896477

[4] Esmond, J. and Dunlop, P. (2004) Developing the Volunteer Motivation Inventory to Assess the Underlying Motivation Drives of Volunteers in Western Australia. Lotterywest Social Research Grant, 1-81.

[5] Song, Y. (2004) Research on the Management of Olympic Volunteers. Beijing Sport University, Beijing.

[6] Song, L. and Zhang, Y. (2012) Motivation and Incentive System of Xi'an Global Garden Expo University Student Volunteers. Journal of Shaanxi Institute of Junior Managerial Personnel, 1, 52-57 \& 73.

[7] Wei, M., et al. (2001) Working in the Heart of APEC-An Interview with Several College Students Volunteers. http://news.eastday.com/epublish/gb/paper111/1/class011100016/hwz513919.htm?e $\underline{\text { fgc3 }}$

[8] Luo, H. (2013) Voluntary Work of University Student Volunteers in Chinese Large Sports Events. Beijing Sport University, Beijing. 
[9] Zhang, J. (2009) Incentive System of University Student Voluntary Service. Ideological and Theoretical Education, 3, 91-93.

[10] Galindo-Kuhn, R. and Guzley, R.M. (2001) The Volunteer Satisfaction Index: Construct Definition, Measurement, Development, and Validation. Journal of Social Service Research, 28, 45-68. https://doi.org/10.1300/J079v28n01_03

[11] Xiao, L. and Huang, L. (2007) A Review of Volunteer Motivation in Foreign Countries. Legal System and Society, 10, 862.

[12] Weiss, D.J., Dawis, R.V., England, G.W. and Lofquist, L.H. (1967) Manual for the Minnesota Satisfaction Questionnaire. Minnesota Studies in Vocational Rehabilitation, Vol. 22.

[13] Capital Civilization Net (2014) Work Situation of 2014 APEC Volunteers from Leader's Week.

http://bj.wenming.cn/zyfw/jx/201411/t20141104_2272201.html 


\section{Appendix}

\section{ANOVA and Coefficient Tables}

Table A1. Difference in motivation dimension among different grades.

\begin{tabular}{|c|c|c|c|c|c|c|}
\hline \multicolumn{7}{|c|}{ ANOVA } \\
\hline & & Sum of squares & $\mathrm{df}$ & Mean square & $\mathrm{F}$ & Sig. \\
\hline \multirow{3}{*}{ Self-growth } & Between groups & 2.229 & 7 & 0.318 & 0.990 & 0.440 \\
\hline & Within group & 55.984 & 174 & 0.322 & & \\
\hline & Total & 58.213 & 181 & & & \\
\hline \multirow{3}{*}{ Social demand } & Between groups & 2.716 & 7 & 0.388 & 0.906 & 0.503 \\
\hline & Within group & 74.538 & 174 & 0.428 & & \\
\hline & Total & 77.254 & 181 & & & \\
\hline \multirow{3}{*}{ Self-realization } & Between groups & 4.180 & 7 & 0.597 & 1.312 & 0.247 \\
\hline & Within group & 79.216 & 174 & 0.455 & & \\
\hline & Total & 83.397 & 181 & & & \\
\hline \multirow{3}{*}{ Altruism } & Between groups & 4.396 & 7 & 0.628 & 1.373 & 0.219 \\
\hline & Within group & 79.563 & 174 & 0.457 & & \\
\hline & Total & 83.959 & 181 & & & \\
\hline \multirow{3}{*}{ Dream realization } & Between groups & 5.915 & 7 & 0.845 & 1.502 & .169 \\
\hline & Within group & 97.887 & 174 & .563 & & \\
\hline & Total & 103.802 & 181 & & & \\
\hline \multirow{3}{*}{ Environmental factor } & Between groups & 11.313 & 7 & 1.616 & 2.800 & 0.009 \\
\hline & Within group & 100.422 & 174 & 0.577 & & \\
\hline & Total & 111.735 & 181 & & & \\
\hline \multirow{3}{*}{ Honor motivation } & Between groups & 11.446 & 7 & 1.635 & 2.395 & 0.023 \\
\hline & Within group & 118.803 & 174 & 0.683 & & \\
\hline & Total & 130.249 & 181 & & & \\
\hline \multirow{3}{*}{$\begin{array}{c}\text { Compensation } \\
\text { exchange }\end{array}$} & Between groups & 14.425 & 7 & 2.061 & 2.117 & 0.044 \\
\hline & Within group & 169.384 & 174 & 0.973 & & \\
\hline & Total & 183.809 & 181 & & & \\
\hline
\end{tabular}


Table A2. Difference in motivation dimension among different gender.

\begin{tabular}{|c|c|c|c|c|c|c|}
\hline \multicolumn{7}{|c|}{ ANOVA } \\
\hline & & Sum of squares & $\mathrm{df}$ & Mean square & $\mathrm{F}$ & Sig. \\
\hline & Between groups & 0.453 & 1 & 0.453 & 1.413 & 0.236 \\
\hline \multirow[t]{3}{*}{ Self-growth } & Within group & 57.760 & 180 & 0.321 & & \\
\hline & Total & 58.213 & 181 & & & \\
\hline & Between groups & 0.625 & 1 & 0.625 & 1.468 & 0.227 \\
\hline \multirow[t]{3}{*}{ Social demand } & Within group & 76.629 & 180 & 0.426 & & \\
\hline & Total & 77.254 & 181 & & & \\
\hline & Between groups & 2.410 & 1 & 2.410 & 5.357 & 0.022 \\
\hline \multirow[t]{3}{*}{ Self-realization } & Within group & 80.987 & 180 & 0.450 & & \\
\hline & Total & 83.397 & 181 & & & \\
\hline & Between groups & 1.627 & 1 & 1.627 & 3.557 & 0.061 \\
\hline \multirow[t]{3}{*}{ Altruism } & Within group & 82.332 & 180 & 0.457 & & \\
\hline & Total & 83.959 & 181 & & & \\
\hline & Between groups & 0.182 & 1 & 0.182 & 0.316 & 0.575 \\
\hline \multirow[t]{3}{*}{ Dream realization } & Within group & 103.621 & 180 & 0.576 & & \\
\hline & Total & 103.802 & 181 & & & \\
\hline & Between groups & 2.627 & 1 & 2.627 & 4.334 & 0.039 \\
\hline \multirow[t]{3}{*}{ Environmental factor } & Within group & 109.107 & 180 & 0.606 & & \\
\hline & Total & 111.735 & 181 & & & \\
\hline & Between groups & 5.923 & 1 & 5.923 & 8.576 & 0.004 \\
\hline \multirow[t]{3}{*}{ Honor motivation } & Within group & 124.325 & 180 & 0.691 & & \\
\hline & Total & 130.249 & 181 & & & \\
\hline & Between groups & 1.557 & 1 & 1.557 & 1.538 & 0.217 \\
\hline \multirow[t]{2}{*}{ Compensation exchange } & Within group & 182.252 & 180 & 1.013 & & \\
\hline & Total & 183.809 & 181 & & & \\
\hline
\end{tabular}


Table A3. Difference in motivation dimension among different ages.

\begin{tabular}{|c|c|c|c|c|c|c|}
\hline \multicolumn{7}{|c|}{ ANOVA } \\
\hline & & Sum of squares & $\mathrm{df}$ & Mean square & $\mathrm{F}$ & Sig. \\
\hline & Between groups & 2.113 & 7 & 0.302 & 0.936 & 0.480 \\
\hline \multirow[t]{3}{*}{ Self-growth } & Within group & 56.100 & 174 & 0.322 & & \\
\hline & Total & 58.213 & 181 & & & \\
\hline & Between groups & 2.720 & 7 & 0.389 & 0.907 & 0.502 \\
\hline \multirow[t]{3}{*}{ Social demand } & Within group & 74.534 & 174 & 0.428 & & \\
\hline & Total & 77.254 & 181 & & & \\
\hline & Between groups & 3.019 & 7 & 0.431 & 0.934 & 0.482 \\
\hline \multirow[t]{3}{*}{ Self-realization } & Within group & 80.377 & 174 & 0.462 & & \\
\hline & Total & 83.397 & 181 & & & \\
\hline & Between groups & 4.980 & 7 & 0.711 & 1.567 & 0.148 \\
\hline \multirow[t]{3}{*}{ Altruism } & Within group & 78.979 & 174 & 0.454 & & \\
\hline & Total & 83.959 & 181 & & & \\
\hline & Between groups & 6.864 & 7 & 0.981 & 1.760 & 0.098 \\
\hline \multirow[t]{3}{*}{ Dream realization } & Within group & 96.938 & 174 & 0.557 & & \\
\hline & Total & 103.802 & 181 & & & \\
\hline & Between groups & 2.469 & 7 & 0.353 & .562 & .786 \\
\hline \multirow[t]{3}{*}{ Environmental factor } & Within group & 109.265 & 174 & 0.628 & & \\
\hline & Total & 111.735 & 181 & & & \\
\hline & Between groups & 6.484 & 7 & 0.926 & 1.302 & .252 \\
\hline \multirow[t]{3}{*}{ Honor motivation } & Within group & 123.765 & 174 & 0.711 & & \\
\hline & Total & 130.249 & 181 & & & \\
\hline & Between groups & 4.076 & 7 & 0.582 & 0.564 & 0.785 \\
\hline \multirow[t]{2}{*}{ Compensation exchange } & Within group & 179.734 & 174 & 1.033 & & \\
\hline & Total & 183.809 & 181 & & & \\
\hline
\end{tabular}


Table A4. Difference in motivation dimension among major.

\begin{tabular}{|c|c|c|c|c|c|c|}
\hline \multicolumn{7}{|c|}{ ANOVA } \\
\hline & & Sum of squares & $\mathrm{df}$ & Mean square & $\mathrm{F}$ & Sig. \\
\hline & Between groups & 0.293 & 1 & 0.293 & 0.909 & 0.342 \\
\hline \multirow[t]{3}{*}{ Self-growth } & Within group & 57.921 & 180 & 0.322 & & \\
\hline & Total & 58.213 & 181 & & & \\
\hline & Between groups & 0.762 & 1 & 0.762 & 1.793 & 0.182 \\
\hline \multirow[t]{3}{*}{ Social demand } & Within group & 76.492 & 180 & 0.425 & & \\
\hline & Total & 77.254 & 181 & & & \\
\hline & Between groups & 0.936 & 1 & 0.936 & 2.042 & 0.155 \\
\hline \multirow[t]{3}{*}{ Self-realization } & Within group & 82.461 & 180 & 0.458 & & \\
\hline & Total & 83.397 & 181 & & & \\
\hline & Between groups & 0.165 & 1 & 0.165 & 0.353 & 0.553 \\
\hline \multirow[t]{3}{*}{ Altruism } & Within group & 83.794 & 180 & 0.466 & & \\
\hline & Total & 83.959 & 181 & & & \\
\hline & Between groups & 0.134 & 1 & 0.134 & 0.232 & .631 \\
\hline \multirow[t]{3}{*}{ Dream realization } & Within group & 103.668 & 180 & 0.576 & & \\
\hline & Total & 103.802 & 181 & & & \\
\hline & Between groups & 0.000 & 1 & 0.000 & 0.000 & 0.999 \\
\hline \multirow[t]{3}{*}{ Environmental factor } & Within group & 111.735 & 180 & 0.621 & & \\
\hline & Total & 111.735 & 181 & & & \\
\hline & Between groups & 3.500 & 1 & 3.500 & 4.970 & 0.027 \\
\hline \multirow[t]{3}{*}{ Honor motivation } & Within group & 126.749 & 180 & 0.704 & & \\
\hline & Total & 130.249 & 181 & & & \\
\hline & Between groups & 1.204 & 1 & 1.204 & 1.187 & 0.277 \\
\hline \multirow[t]{2}{*}{ Compensation exchange } & Within group & 182.605 & 180 & 1.014 & & \\
\hline & Total & 183.809 & 181 & & & \\
\hline
\end{tabular}


Table A5. Difference in motivation dimension among different political status.

\begin{tabular}{|c|c|c|c|c|c|c|}
\hline \multicolumn{7}{|c|}{ ANOVA } \\
\hline & & Sum of squares & $\mathrm{df}$ & Mean square & $\mathrm{F}$ & Sig. \\
\hline \multirow{3}{*}{ Self-growth } & Between groups & 0.618 & 1 & 0.618 & 1.932 & 0.166 \\
\hline & Within group & 57.595 & 180 & 0.320 & & \\
\hline & Total & 58.213 & 181 & & & \\
\hline \multirow{3}{*}{ Social demand } & Between groups & 0.226 & 1 & 0.226 & .528 & .468 \\
\hline & Within group & 77.028 & 180 & 0.428 & & \\
\hline & Total & 77.254 & 181 & & & \\
\hline \multirow{3}{*}{ Self-realization } & Between groups & .449 & 1 & 0.449 & 0.973 & 0.325 \\
\hline & Within group & 82.948 & 180 & 0.461 & & \\
\hline & Total & 83.397 & 181 & & & \\
\hline \multirow{3}{*}{ Altruism } & Between groups & 0.632 & 1 & 0.632 & 1.364 & 0.244 \\
\hline & Within group & 83.327 & 180 & 0.463 & & \\
\hline & Total & 83.959 & 181 & & & \\
\hline \multirow{3}{*}{ Dream realization } & Between groups & 1.962 & 1 & 1.962 & 3.468 & 0.064 \\
\hline & Within group & 101.840 & 180 & 0.566 & & \\
\hline & Total & 103.802 & 181 & & & \\
\hline \multirow{3}{*}{ Environmental factor } & Between groups & 0.411 & 1 & 0.411 & 0.665 & 0.416 \\
\hline & Within group & 111.323 & 180 & 0.618 & & \\
\hline & Total & 111.735 & 181 & & & \\
\hline \multirow{3}{*}{ Honor motivation } & Between groups & 8.028 & 1 & 8.028 & 11.823 & 0.001 \\
\hline & Within group & 122.221 & 180 & 0.679 & & \\
\hline & Total & 130.249 & 181 & & & \\
\hline \multirow{3}{*}{$\begin{array}{c}\text { Compensation } \\
\text { exchange }\end{array}$} & Between groups & 1.110 & 1 & 1.110 & 1.094 & 0.297 \\
\hline & Within group & 182.699 & 180 & 1.015 & & \\
\hline & Total & 183.809 & 181 & & & \\
\hline
\end{tabular}


Table A6. Relationship between overall motivation and job satisfaction.

\begin{tabular}{|c|c|c|c|c|c|c|}
\hline \multicolumn{7}{|c|}{ Coefficient $^{\mathrm{a}}$} \\
\hline & \multirow{2}{*}{ Model } & \multicolumn{2}{|c|}{ Model } & \multirow{2}{*}{$\begin{array}{c}\text { Model } \\
\text { Trial }\end{array}$} & \multirow{2}{*}{ Model } & \multirow{2}{*}{ Mode } \\
\hline & & $\mathrm{B}$ & Standard error & & & \\
\hline \multirow{6}{*}{1} & (Constant) & 2.969 & 0.935 & & 3.177 & 0.002 \\
\hline & 102 & -0.098 & 0.066 & -0.233 & -1.483 & 0.140 \\
\hline & 103 & -0.140 & 0.093 & -0.121 & -1.503 & 0.135 \\
\hline & 104 & 0.079 & 0.049 & 0.241 & 1.611 & 0.109 \\
\hline & 105 & 0.041 & 0.088 & 0.038 & 0.473 & 0.637 \\
\hline & 106 & -0.016 & 0.097 & -0.014 & -0.164 & 0.870 \\
\hline \multirow{7}{*}{2} & (Constant) & 2.187 & 0.828 & & 2.642 & 0.009 \\
\hline & 102 & -0.008 & 0.059 & -0.019 & -0.138 & 0.890 \\
\hline & 103 & -0.077 & 0.082 & -0.067 & -0.940 & 0.348 \\
\hline & 104 & 0.017 & 0.044 & 0.052 & 0.388 & 0.698 \\
\hline & 105 & -0.002 & 0.077 & -0.002 & -0.028 & 0.978 \\
\hline & 106 & -0.101 & 0.086 & -0.088 & -1.179 & 0.240 \\
\hline & Overall motivation & 0.486 & 0.067 & 0.494 & 7.298 & 0.000 \\
\hline
\end{tabular}

a. Dependent variable: Job satisfaction.

Table A7. Relationship between each motivation dimension and job satisfaction.

\begin{tabular}{|c|c|c|c|c|c|c|}
\hline \multicolumn{7}{|c|}{ Coefficient $^{a}$} \\
\hline & \multirow{2}{*}{ Model } & \multicolumn{2}{|r|}{ Model } & \multirow{2}{*}{$\begin{array}{c}\text { Model } \\
\text { Trial }\end{array}$} & \multirow{2}{*}{ Model } & \multirow{2}{*}{ Mode } \\
\hline & & B & Standard error & & & \\
\hline \multirow{6}{*}{1} & (Constant) & 2.969 & 0.935 & & 3.177 & 0.002 \\
\hline & 102 & -0.098 & 0.066 & -0.233 & -1.483 & 0.140 \\
\hline & 103 & -0.140 & 0.093 & -0.121 & -1.503 & 0.135 \\
\hline & 104 & 0.079 & 0.049 & 0.241 & 1.611 & 0.109 \\
\hline & 105 & 0.041 & 0.088 & 0.038 & 0.473 & 0.637 \\
\hline & 106 & -0.016 & 0.097 & -0.014 & -0.164 & 0.870 \\
\hline \multirow{14}{*}{2} & (Constant) & 1.948 & 0.830 & & 2.347 & 0.020 \\
\hline & 102 & -0.024 & 0.058 & -0.057 & -0.412 & 0.681 \\
\hline & 103 & -0.078 & 0.081 & -0.067 & -0.953 & 0.342 \\
\hline & 104 & 0.013 & 0.043 & 0.039 & 0.297 & 0.767 \\
\hline & 105 & 0.023 & 0.076 & 0.021 & 0.304 & 0.761 \\
\hline & 106 & -0.098 & 0.087 & -0.085 & -1.128 & 0.261 \\
\hline & Self growth & 0.115 & 0.125 & 0.122 & 0.922 & 0.358 \\
\hline & Social demand & 0.104 & 0.099 & 0.127 & 1.049 & 0.296 \\
\hline & Self realization & 0.051 & 0.072 & 0.065 & 0.710 & 0.479 \\
\hline & Altruism & 0.156 & 0.084 & 0.198 & 01.851 & 0.066 \\
\hline & Dream realization & 0.052 & 0.077 & 0.074 & 0.681 & 0.497 \\
\hline & Environmental factor & 0.074 & 0.064 & 0.108 & 1.161 & 0.247 \\
\hline & Honor motivation & 0.026 & 0.061 & 0.042 & 0.433 & 0.665 \\
\hline & Compensation exchange & -0.060 & 0.045 & -0.114 & -1.340 & 0.182 \\
\hline
\end{tabular}

a. Dependent variable: Job satisfaction. 